SAINS TANAH - Journal of Soil Science and Agroclimatology

Journal homepage: http://jurnal.uns.ac.id/tanah

\title{
Estimates of methane and nitrous oxide emission from a rice field in Central Java, Indonesia, based on the DeNitrification DeComposition model
}

\author{
Umi Munawaroh ${ }^{1}$, Komariah $^{2 *}$, Dwi Priyo Ariyanto ${ }^{2}$, Muhamad Khoiru Zaki ${ }^{3}$, Keigo Noda ${ }^{3}$ \\ ${ }^{1}$ Master Program of Soil Science Department, Postgraduate School, Sebelas Maret University, Indonesia \\ ${ }^{2}$ Department of Soil Science, Faculty of Agriculture, Sebelas Maret University, Indonesia \\ ${ }^{3}$ Faculty of Applied Biological Sciences, Gifu University, Japan
}

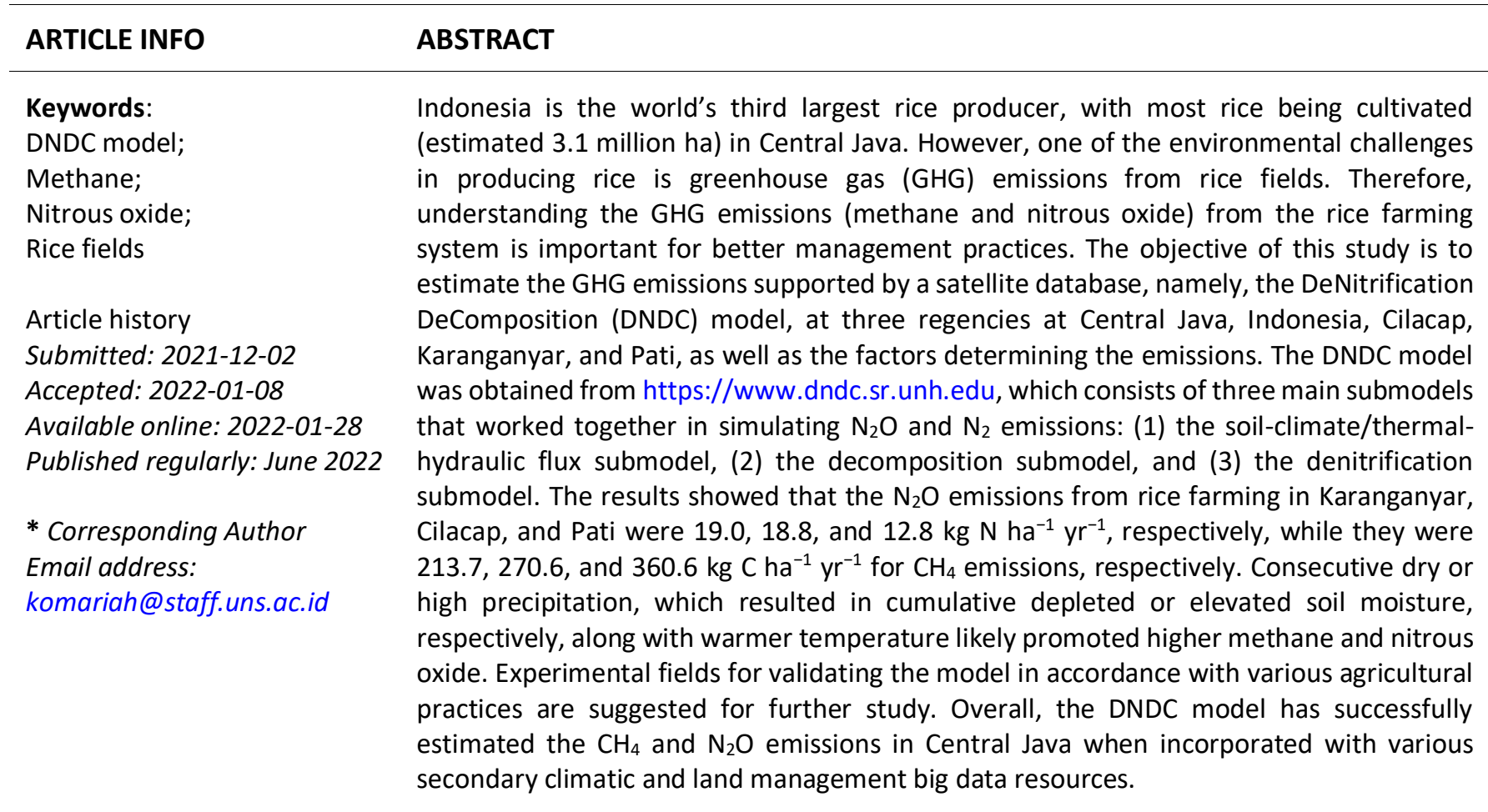

\begin{abstract}
How to Cite: Munawaroh, U., Komariah, Ariyanto, D.P., Zaki, M.K., \& Noda, K. (2022). Estimates of methane and nitrous oxide emission from a rice field in Central Java, Indonesia, based on the DeNitrification DeComposition model. Sains Tanah Journal of Soil Science and Agroclimatology, 19(1): 1-11. https://dx.doi.org/10.20961/stjssa.v19i1.56928
\end{abstract}

\section{INTRODUCTION}

Rice is the most important staple food crop for more than 3 billion people in the world (Birla et al., 2017). World rice consumption is projected to increase from 450 million tons in 2011 to around 490 million tons in 2020 and to around 650 million tons in 2050 (Muthayya et al., 2014). Rice cultivation is a major source of atmospheric methane $\left(\mathrm{CH}_{4}\right)$ and nitrous oxide $\left(\mathrm{N}_{2} \mathrm{O}\right)$, which are significant potential greenhouse gases (GHGs) and are responsible for approximately $11 \%\left(\mathrm{CH}_{4}\right)$ and $60 \%\left(\mathrm{~N}_{2} \mathrm{O}\right)$ of global anthropogenic emissions (Ciais et al., 2013). Methane emissions from rice fields are a net result of the production and oxidation of $\mathrm{CH}_{4}$ in the soil and the transport of $\mathrm{CH}_{4}$ gas from the soil to the atmosphere through rice plants (Minamikawa et al., 2014). Conventional management practices of continuous inundation of irrigation in rice fields increase the anaerobic fermentation of carbon sources supplied by rice plants, add organic matter, and result in high $\mathrm{CH}_{4}$ production.

Rice fields are also known to emit high nitrous oxide $\left(\mathrm{N}_{2} \mathrm{O}\right)$ fluxes under nitrogen fertilization (Xu et al., 2015) and certain water management regimes (Oo et al., 2018). Most of the $\mathrm{N}_{2} \mathrm{O}$ emissions come from the application of fertilizers and animal manure (Seitzinger \& Phillips, 2017; Smith, 2017). $\mathrm{N}_{2} \mathrm{O}$ emissions are currently increasing at a rate of $0.25 \%$ per year (Beaulieu et al., 2011), from agricultural activities, globally, namely, from Asia (63\%), America (20\%), Europe (13\%), and Africa (3\%) between 2001 and 2011 (Tubiello et al., 2014). 
Therefore, measuring agricultural emissions $\left(\mathrm{CH}_{4}\right.$ and $\left.\mathrm{N}_{2} \mathrm{O}\right)$ and finding suitable mitigation measures have become important tasks in current scientific research with a focus on climatic conditions such as rainfall, soil moisture, and temperature.

The DeNitrification DeComposition (DNDC) model is a high-efficiency tool for simulating rice yields and for capturing $\mathrm{CH}_{4}$ and $\mathrm{N}_{2} \mathrm{O}$ emissions from different rice production systems (Zhang et al., 2021). In addition, many studies have modified and optimized the DNDC model (Han et al., 2014; Zhang et al., 2019), which can simulate soil temperature and moisture accurately. Temperature and humidity are very important for nitrification and denitrification because they determine the activity of microorganisms. In addition, soil temperature and humidity greatly affect not only the production of $\mathrm{CH}_{4}$ and $\mathrm{N}_{2} \mathrm{O}$ but also their diffusion into the atmosphere. In general, a decrease in moisture has an effect on $\mathrm{N}_{2} \mathrm{O}$ emissions, while greater soil moisture has an effect on $\mathrm{CH}_{4}$ emissions (Liu et al., 2017; Oo et al., 2018). This happens because soil moisture content is associated with microbial activity: the higher soil moisture, the higher microbial activity, and vice versa.

Chamber measurements of $\mathrm{CH}_{4}$ and $\mathrm{N}_{2} \mathrm{O}$ emissions provide satisfactory data on site-specific, pots, and laboratory experiments (Kim et al., 2021); however, due to soil, climate, and plant diversity, as well as soil and plant management, it is difficult to scale up these data (Abdalla et al., 2020; Li et al., 2017). Scale up techniques and simulation models that are dynamic enough to account for the spatial and temporal variability inherent in these emissions are urgently needed. The right model will increase the reliability of temporal and spatial integration and help identify knowledge gaps. Several simulation models describing the dynamics of nitrogen in the soil have been developed such as CENTURY, EXPERT-N, DAYCENT, and DNDC. The DNDC model is widely accepted and used, simulating two microbial-mediated processes, nitrification and denitrification, which are mainly processed in the soil to produce $\mathrm{N}_{2} \mathrm{O}$ (Gilhespy et al., 2014; Zhao et al., 2020). In the DNDC model, denitrification is activated by the redox potential of the soil (Li et al., 1992a, 1992b). This model can be used for many crops and provides daily and seasonal evolution of $\mathrm{CH}_{4}$ and $\mathrm{N}_{2} \mathrm{O}$ from agricultural soils at a field scale, using available input data (Oo et al., 2018).

Indonesia is the third largest rice producer in the world and the world's largest rice consumer. The total area of rice fields reached around 13.8 million ha in 2016 (BPS, 2021), with Java being the second largest rice field area in Indonesia, which contributes to national rice productivity (Susilawati et al., 2015) and contributes to the average emission from rice fields in Indonesia of $0.18 \mathrm{t} \mathrm{CH}_{4}$ ha $^{-1}$, with Java $1,146 \mathrm{Gg} \mathrm{CH}_{4}$ $\mathrm{yr}^{-1}, 691 \mathrm{Gg} \mathrm{CH}_{4} \mathrm{yr}^{-1}$ for Sumatra, $324 \mathrm{Gg} \mathrm{CH}_{4} \mathrm{yr}^{-1}$ for Sulawesi, $206 \mathrm{Gg} \mathrm{CH}_{4} \mathrm{yr}^{-1}$ for Kalimantan, $103 \mathrm{Gg} \mathrm{CH}_{4} \mathrm{yr}^{-1}$ for Nusa Tenggara, $25 \mathrm{Gg} \mathrm{CH}_{4} \mathrm{yr}^{-1}$ for Bali, and $10 \mathrm{Gg} \mathrm{CH}_{4} \mathrm{yr}^{-1}$ for Papua (Ariani et al., 2021). These $\mathrm{CH}_{4}$ emission values are based on field measurements without studies of specific duration that are not well documented in peer-reviewed publications (Ariani et al., 2021).

Furthermore, researchers focus more on studies of $\mathrm{CH}_{4}$ and $\mathrm{N}_{2} \mathrm{O}$ emissions using the chamber method at a laboratory-field scale with various factors such as organic matter (Nungkat et al., 2015) and irrigation practices (Setyanto et al., 2018). This makes research on GHG emissions in rice fields still limited to large areas. Yet, to the best our knowledge, the studies on $\mathrm{CH}_{4}$ and $\mathrm{N}_{2} \mathrm{O}$ emissions in rice fields using the DNDC model with large areas are still limited. There are many challenges for application in Indonesia, particularly sparse data and data infrastructure is not the same for all provinces. Therefore, starting from Java Islands, where the data infrastructure is better than other provinces, and Central Java, as one of the national rice baskets of Indonesia, the aim of this study was to estimate the $\mathrm{CH}_{4}$ and $\mathrm{N}_{2} \mathrm{O}$ emissions with a focus on precipitation, soil moisture, temperature, and rice production in Central Java. The estimation and monitoring of GHG emissions in rice fields can contribute to hunger reduction (Sustainable Development Goal-SDG2), ensure a climate safety net for food production (SDG 13), and sustainably manage forests from land degradation (SDG 15).

\section{MATERIALS AND METHODS}

\subsection{Study sites}

Since 1980, Indonesia's national rice yield has been the highest in tropical Asia (GRiSP, 2013). Also, Indonesia has one of the largest rice consumers in the world, averaging more than $200 \mathrm{~kg}$ per head each year (Connor et al., 2021). Rice is grown across the major islands of Indonesia, but most rice is cultivated on the island of Java on an estimated 3.1 million ha of land (Ministry of Agriculture, 2018). The study was conducted in Central Java, in Cilacap $\left(7.45^{\circ} \mathrm{S}, 109.01^{\circ} \mathrm{E}\right)$, Karanganyar $\left(7.36^{\circ} \mathrm{S}, 110.05^{\circ} \mathrm{E}\right)$, and Pati $\left(6.46^{\circ} \mathrm{S}, 111.07^{\circ} \mathrm{E}\right)$, from 2005 to 2010, as shown in Figure 2.

\subsection{Calculation using the DNDC model}

The DNDC model was obtained from https://www.dndc.sr.unh.edu, which consists of three main submodels (Figure 1 ) that work together in simulating $\mathrm{N}_{2} \mathrm{O}$ and $\mathrm{N}_{2}$ emissions: (1) soil-climate/thermal-hydraulic flux submodel, (2) decomposition submodel, and (3) denitrification submodel.

\subsubsection{Thermohydraulic submodel}

The thermohydraulic submodel calculates hourly and daily mean soil temperatures and soil moisture profiles. To do so, DNDC uses a cascade model approach in which the soil is divided into a series of horizontal layers, assuming that each layer has uniform temperature and humidity. Both temperature and humidity calculations are gradient-driven equations. This flux is created by the average daily air temperature and the temperature of the soil layer at a certain depth (Li et al., 1992a). To calculate the temperature, it is assumed that there is a simplified heat flux between the ground surface and the atmosphere (see also equations 1-3). In soil moisture simulation, evapotranspiration is used as the output, while rainfall and irrigation are combined as the inputs. The water input is always calculated as if the input starts at midnight and the intensity is constant, and thus, the duration varies. At the beginning of each time step, the water input fills the soil layer by layer. So, excess water from one layer fills the next deeper layer. Surface runoff and water intercepted from vegetation are not taken into account in this initial version (as shown by Equation 4). 


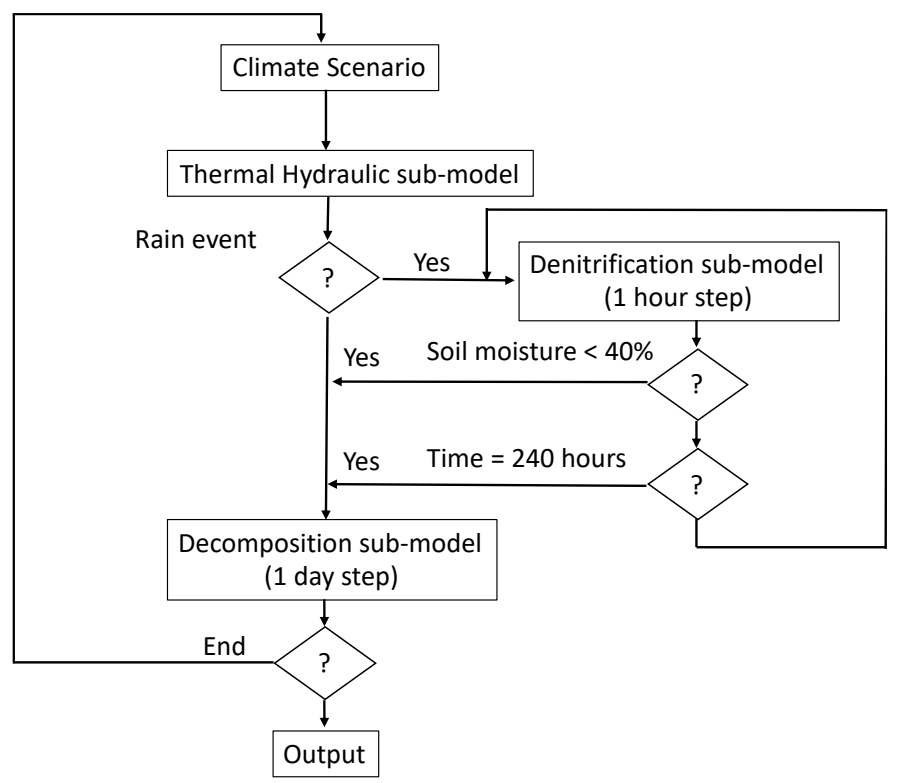

Figure 1. Structure of the DNDC model incorporating three submodels (Li et al., 1992a).

$\mathrm{q}_{\mathrm{s}}=\frac{(T 1-T a i r)}{(z 1-0)} \times-\mathrm{k}_{1}$, Soil heat flux at the surface

$\mathrm{q}_{\mathrm{i}, \mathrm{i}-1}=\frac{\left(T_{i}-T_{i-1}\right)}{Z_{i}-Z_{i-1}} \times-\mathrm{k}_{\mathrm{i}, \mathrm{i}-1}$, Soil heat flux

(layer $i-1$-> layer $i$ )

$q_{b}=\left(T_{b l}-T_{\text {mean }}\right)\left(Z_{b l}-Z_{\text {deep }}\right) \times k_{b l}$, Soil heat flux at the bottom of the profile

$E_{0}=D A Y_{1} *\left(\frac{1,6}{N M}\right) *\left(10 * \frac{T n^{\prime}}{I}\right)^{a}$, Potential evapotranspiration

where $q_{s}$ is the heat flux at the soil surface $\left(\mathrm{J} \mathrm{s}^{-1}\right), \mathrm{q}_{\mathrm{i}, \mathrm{i}-1}$ is the heat flux from layer $\mathrm{i}-1$ down to layer $\mathrm{i}\left(\mathrm{J} \mathrm{s}^{-1}\right), \mathrm{q}_{\mathrm{b}}$ is the heat flux at the bottom of the profile $\left(\mathrm{J} \mathrm{s}^{-1}\right), K_{1}$ is the soil thermal conductivity of layer 1 (soil surface) $\left(\mathrm{J} \mathrm{cm} \mathrm{g}^{-1}{ }^{\circ} \mathrm{C}^{-1}\right), K_{\mathrm{i}, \mathrm{i}-1}$ is the average thermal conductivity of layers I and $\mathrm{i}-1\left(\mathrm{~J} \mathrm{~cm} \mathrm{~g}^{-1}{ }^{\circ} \mathrm{C}^{-1}\right)$, $K_{\mathrm{bl}}$ is the average thermal conductivity at the bottom of the

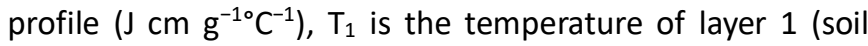
surface) $\left({ }^{\circ} \mathrm{C}\right), \mathrm{T}_{\mathrm{i}}$ is the temperature for level $\mathrm{i}\left({ }^{\circ} \mathrm{C}\right), \mathrm{T}_{\mathrm{bl}}$ is the temperature at the bottom of the profile $\left({ }^{\circ} \mathrm{C}\right), \mathrm{T}_{\text {air }}$ is the air temperature $\left({ }^{\circ} \mathrm{C}\right), \mathrm{T}_{\text {mean }}$ is the mean annual air temperature $\left({ }^{\circ} \mathrm{C}\right), Z_{b l}$ is the depth at the bottom of the profile $(\mathrm{cm})$, and $Z_{\text {deep }}$ is the depth where temperature variation is assumed to be negligible $(500 \mathrm{~cm})$. $\mathrm{E}_{0}$ is the potential evapotranspiration $(\mathrm{cm}$ $\left.\mathrm{d}^{-1}\right), D A Y_{1}$ equals $1 / 12$ of the day's hours of daylight, $N M$ is the
[1] number of days in the month, $T_{n}{ }^{\prime}$ is the mean monthly air temperature of month $n\left({ }^{\circ} \mathrm{C}\right)$,

$a=0,49+(0,079 \times I)-\left(7,71 e^{-5} \times I^{2)}+\left(6,75 e-7 \times I^{3}\right)\right.$

2] where $I=\sum_{n=1}^{12} \frac{T^{\prime} 1,5}{5}$. EO is zero for months where the mean air temperature is below $0^{\circ} \mathrm{C}$.

\section{3] 2.2. Soil decomposition submodel}

The soil decomposition submodel alternated with the soil denitrification submodel, depending on the simulated soil oxygen content. In the soil decomposition model, the soil profile was divided into uniform horizontal layers with a typical thickness of $2 \mathrm{~cm}$. Counting layer by layer in daily time steps, the three organic assemblages are determined (decomposable plant material residues, microbial and humid biomass), and their corresponding labile and resistant compartments decompose via first-order kinetics, as shown in Equations 5, 6, and 7.

$\frac{d C}{d t}=\mu_{\mathrm{CLAY}} \times \mu_{\mathrm{CN}} \times \mu_{\mathrm{tn}} \times\left(\mathrm{S} \times \mathrm{k}_{1}+(1-\mathrm{S}) \times \mathrm{k}_{\mathrm{r}}\right)$

$\mu_{\mathrm{CLAY}}=\log \frac{0.14}{C L A Y}+1$

$\mu \mathrm{CN}=0.2+\frac{7.2}{C P / N P}$

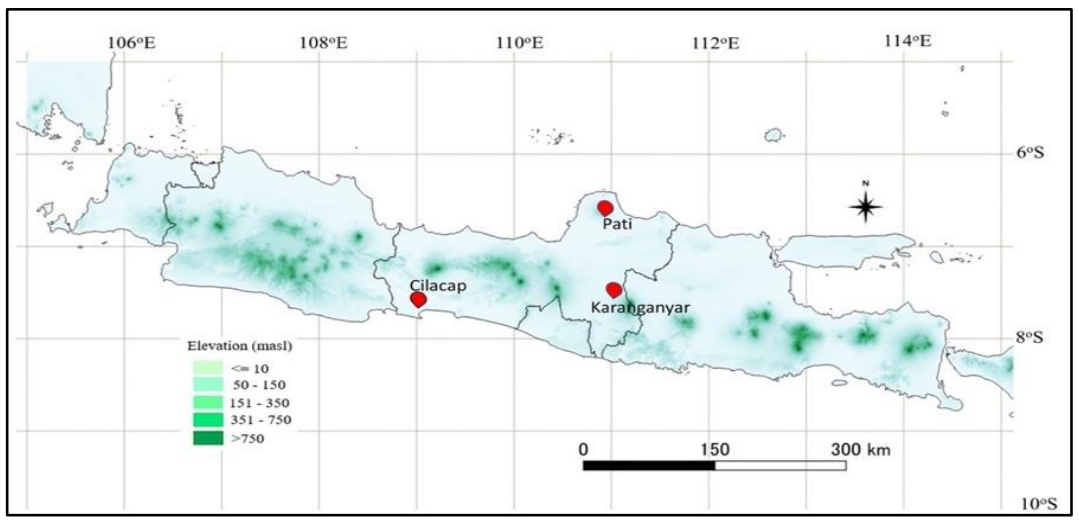

Figure 2. Study sites for $\mathrm{CH}_{4}$ and $\mathrm{N}_{2} \mathrm{O}$ estimation. 
where $\mu_{\mathrm{CLAY}}$ is the clay content reduction factor, $\mu_{\mathrm{CN}}$ is the $\mathrm{C} / \mathrm{N}$ ratio reduction factor, $\mu_{\mathrm{tn}}$ is the temperature reduction factor for nitrification, $\mathrm{S}$ is the labile fraction of organic $\mathrm{C}$ compounds in the pool, $K_{1}$ is the specific decomposition rate (SDR) of labile fraction $\left(d_{-1}\right), K_{r}$ is the SDR of the resistant fraction $(d-1)$, CLAY is the soil clay fractional content, CP is the carbon produced by potential residue decomposition $\left(\mathrm{kg} \mathrm{C} \mathrm{ha}^{-1} \mathrm{~d}^{-1}\right)$, and NP is the nitrogen produced by potential residue decomposition plus free $\mathrm{NH}_{4}{ }^{+}$and $\mathrm{NO}_{3}{ }^{-}$in the soil $\left(\mathrm{kg} \mathrm{N} \mathrm{ha}^{-1}\right)$.

Oxidation of organic $\mathrm{C}$ causes the release of $\mathrm{NH}_{4}^{+}$, which is nitrified or evaporated. In nitrification, the rate of nitrification potential is related to available $\mathrm{NH}_{4}{ }^{+}$, soil temperature, and soil moisture (see Equation 8). The model calculations simulate the nitrification rate as a function of these three factors, assuming an optimal rate at $35^{\circ} \mathrm{C}$ and $90 \%$ soil moisture. In model calculations, $\mathrm{N}_{2} \mathrm{O}$ emission from nitrification (Equation 9) is controlled directly by soil ammonium concentration, temperature being the ratedetermining factor (Li et al., 1992a). During nitrification, the amount of $\mathrm{N}_{2} \mathrm{O}$ emitted in the soil correlates with the amount of $\mathrm{N}$ that can be nitrified in the soil. In DNDC, $\mathrm{NH}_{4}{ }^{+}$is the direct factor controlling $\mathrm{N}_{2} \mathrm{O}$ emission under aerobic conditions. The $\mathrm{N}_{2} \mathrm{O}$ emission from the nitrification process was modeled as a function of soil temperature and soil ammonium concentration.

$\mathrm{dNNO}=\mathrm{NH}_{4}(\mathrm{t}) \times\left[1-\mathrm{ex}\left(-\mathrm{K}_{35} \times \mu_{\mathrm{t}, \mathrm{n}} \times \mathrm{dt}\right)\right] \times \mu_{\mathrm{m}, \mathrm{n}}$,

Nitrification rate

$\mathrm{N}_{2} \mathrm{O}=\left(0.0014 \times \frac{N H 4}{30.0}\right) \times \frac{(0.54+0.51 \times T)}{15.8}$,

$\mathrm{N}_{2} \mathrm{O}$ emitted during nitrification

where dNNO is the $\mathrm{NH}_{4}^{+}$converted to $\mathrm{NO}_{3}^{-}\left(\mathrm{kg} \mathrm{N} \mathrm{ha}^{-1} \mathrm{~d}^{-1}\right)$ $\mathrm{NH}_{4}(\mathrm{t})$ is the available $\mathrm{NH}_{4}{ }^{+}$at time $t\left(\mathrm{~kg} \mathrm{~N} \mathrm{ha}^{-1}\right), \mathrm{K}_{35}$ is the nitrification rate at $35^{\circ} \mathrm{C}(25)\left(\mathrm{mg} \mathrm{kg}^{-1}\right.$ soil $\left.\mathrm{d}^{-1}\right), \mu_{\mathrm{t}, \mathrm{n}}$ is the temperature reduction factor for nitrification, and $\mu_{m, n}$ is the moisture reduction factor for nitrification. $\mathrm{N}_{2} \mathrm{O}$ is the daily emission of $\mathrm{N}_{2} \mathrm{O}, \mathrm{NH}_{4}$ is the $\mathrm{NH}_{4}{ }^{+}$concentration in the liquid phase $\left.(\mathrm{mol} \mathrm{cm})^{-3}\right)$, and $\mathrm{T}$ is the temperature $\left({ }^{\circ} \mathrm{C}\right)$.

\subsubsection{Denitrification submodel}

The denitrification submodel was activated at each rainfall, and here, the soil was divided into layers $2 \mathrm{~cm}$ thick, with corresponding uniform properties. Rainfall events take place as long as the relative humidity (the fraction of pores filled with water) was above $40 \%$. Denitrification begins as soon as the layer is saturated with water, and at this time, only the denitrifier is considered active. In addition, temperature and $\mathrm{pH}$ conditions are also affected by denitrification. The growth of denitrifying bacteria is proportional to their respective biomass. Regarding the emissions of $\mathrm{N}_{2}$ and $\mathrm{N}_{2} \mathrm{O}$, the emission is modeled as a function of both the adsorption coefficient and the air-filled porosity, as shown in Equations 10 and 11. Thus, during rain, when the soil layer is saturated, the diffusion of $\mathrm{N}_{2}$, and $\mathrm{N}_{2} \mathrm{O}$ is neglected because the expected diffusion rate is low. The effect of soil depth is not taken into account because denitrification is concentrated at the soil surface (Li et al., 1992b).

$\mathrm{N}_{2}=0.017+((0.025-0.0013 \times \mathrm{AD}) \times \mathrm{PA})$

$\mathrm{N}_{2} \mathrm{O}=(0.0006+0.0013 \times A D)+(0.013-0.005 \times A D) \times P A$
Where: $\mathrm{N}_{2}$ and $\mathrm{N}_{2} \mathrm{O}$ are emissions from soil; $P\left(\mathrm{~N}_{2}\right)$ is the emitted fraction of the total $N_{2}$ evolved in a day, $A D$ is the adsorption factor depending on clay content in the soil (range $=0-2)$, PA is the air-filled fraction of the total porosity, $\mathrm{P}\left(\mathrm{N}_{2} \mathrm{O}\right)$ is the emitted fraction of the total $\mathrm{N}_{2} \mathrm{O}$ evolved in a day, $A D$ is the adsorption factor depending on clay content in the soil (range $=0-2$ ), and PA is the air-filled fraction of the total porosity.

\subsection{DNDC input parameters}

The DNDC model by (Li et al., 1992a, 1992b) provides daily and seasonal $\mathrm{N}_{2} \mathrm{O}$ evolution from agricultural soils at the field scale using readily available input data. In this study, inputs are required in three different areas. First, climate files consisting of daily precipitation and air temperatures were collected from APHRODITE (http://aphrodite.st.hirosakiu.ac.jp/). Second, soil surface properties including texture, bulk density, $\mathrm{pH}$, and total organic carbon were collected from the WoSIS database (https://data.isric.org/geonetwork/srv/eng/catalog.search\#/ home) and a previous study in the study site. Last, pertinent management variables such as crop selection, timing and the amount of fertilizer $\mathrm{N}$, and manure applications were determined based on the Policy of Agriculture Ministry about recommendation for paddy fertilization in Indonesia (Husnain et al., 2020). The rice yield data were obtained based on The Indonesia Statistical Institute (BPS, 2021) from year 20052010 over the study sites.

Furthermore, weeds and irrigation can also be included. Outputs include annual and daily fluxes of $\mathrm{C}$ including $\mathrm{CO}_{2}$, $\mathrm{CH}_{4}$, dissolved organic carbon, and labile and resistant pools of soil organic carbon. Similarly, annual and daily fluxes of $\mathrm{N}$, including $\mathrm{N}_{2} \mathrm{O}, \mathrm{N}_{2}, \mathrm{NO}$, and $\mathrm{NH}_{3}$, are the outputs.

\subsection{Statistical analysis}

Two-way ANOVA was conducted with the R software. The mean values were compared with least significant difference tests at the 0.05 level of probability. Linear regression and correlation analyses were conducted to evaluate relationships between response variables.

\section{RESULTS}

\subsection{Climate, soil moisture, and rice production}

The characteristics climate, soil moisture, and rice production were analyzed at each study site. In study site, the rainy season occurred in December, January, and February, where most of the precipitation falls. Dry season occurred in June, July, and August, where precipitation is less than $50 \mathrm{~mm}$ for 20 consecutive days; meteorological drought may occur (BMKG, 2019). Figure 3 shows that the total annual rainfall $\left(\mathrm{mm} \mathrm{yr}^{-1}\right)$ and average annual temperature $\left({ }^{\circ} \mathrm{C}\right)$ was 2724.3 and 26.89; 2471.2 and 22.24; 2395.61 and 28.27 for Cilacap, Karanganyar, and Pati, respectively. The highest precipitation was $34.38 \mathrm{~mm}$ day $^{-1}$ that occurred in Pati during the period of 2005-2010.

Consider that agricultural (rice) productivity is directly related to climatic conditions. The results showed that rice 


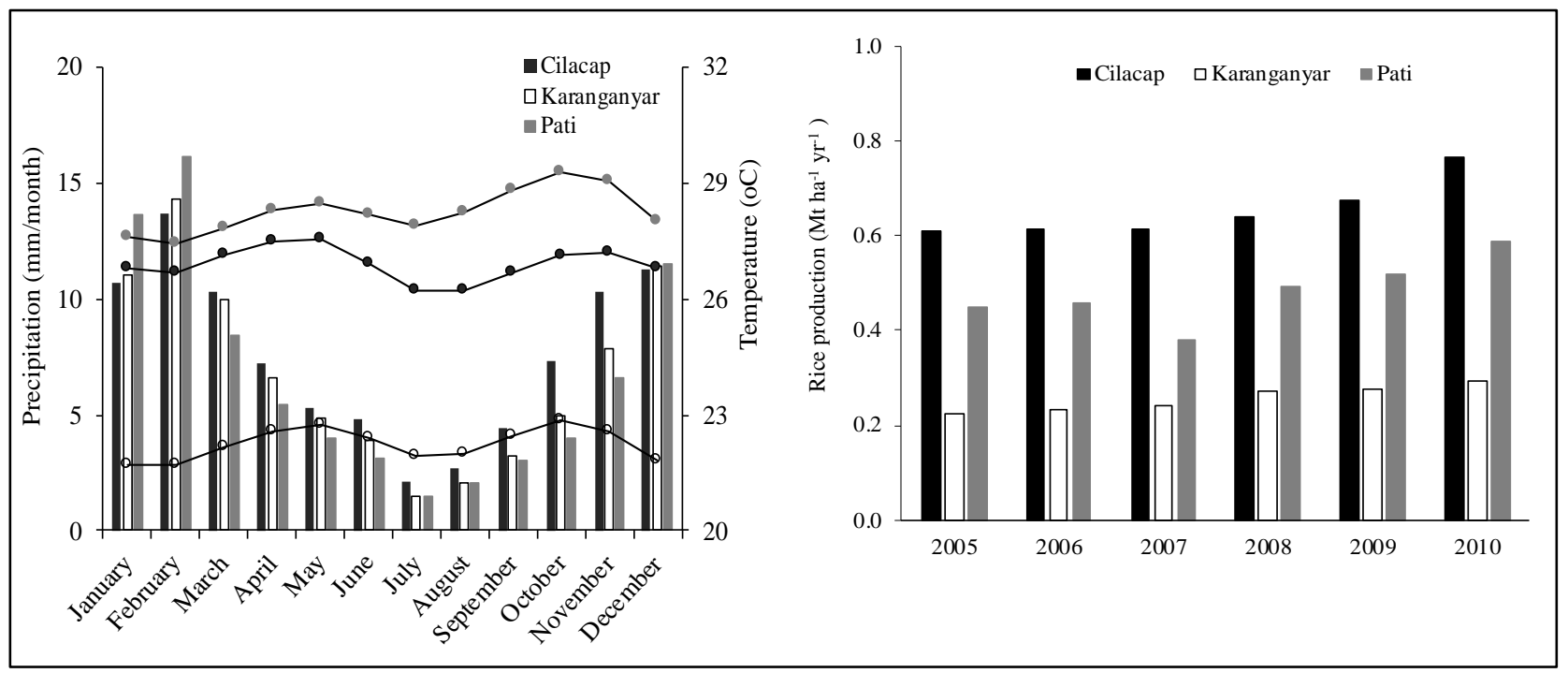

Figure 3. Climate (left) and rice production (right) over study sites.

production ( $\mathrm{Mt} \mathrm{ha}^{-1} \mathrm{yr}^{-1}$ ) increased significantly during the period of 2005-2010, that is, 0.61-0.77 Mt ha-1 $\mathrm{yr}^{-1}$ for Cilacap, 0.22-0.29 $\mathrm{Mt} \mathrm{ha}^{-1} \mathrm{yr}^{-1}$ for Karanganyar, and 0.45$0.59 \mathrm{Mt} \mathrm{ha}^{-1} \mathrm{yr}^{-1}$ for Pati (Figure 3).

\subsection{Seasonal variability of $\mathrm{CH}_{4}$ uptake and $\mathrm{N}_{2} \mathrm{O}$ emission}

Figure 4 shows the seasonal variability of $\mathrm{CH}_{4}$ and $\mathrm{N}_{2} \mathrm{O}$ fluxes with climate and soil moisture over the study sites throughout the period of rice growth from 2005 to 2010. The large $\mathrm{N}_{2} \mathrm{O}$ emissions occurred under dry conditions when the soil moisture ranged $30 \%-40 \%$, where statistical analysis showed that there is a high correlation between precipitation and soil moisture to $\mathrm{N}_{2} \mathrm{O}$ emission in rice fields. Meanwhile, large $\mathrm{CH}_{4}$ emissions occurred under wet conditions. A validation of soil water content estimation was analyzed, where the average soil moisture values over the study sites from 2005 to 2010 are $75.1 \%, 79.6 \%$, and $82.6 \%$ for Karanganayar, Cilacap, and Pati, respectively.

Karanganyar Regency was found to have lower soil moisture causing the highest total $\mathrm{N}_{2} \mathrm{O}$ emission up to $19 \mathrm{~kg}$ $\mathrm{N}$ ha ${ }^{-1} \mathrm{yr}^{-1}$ than Cilacap and Pati (18.8 and $12.8 \mathrm{~kg} \mathrm{~N} \mathrm{ha}^{-1} \mathrm{yr}^{-1}$, respectively). Meanwhile, Pati has the higher average soil moisture $\left(82.6 \%\right.$ ) causing enhanced $\mathrm{CH}_{4}$ emission (360 kg C $\mathrm{ha}^{-1} \mathrm{yr}^{-1}$ ) compared with Cilacap (270.6 kg C ha-1 $\mathrm{yr}^{-1}$ ) and Karanganyar (213.7 kg C ha- $\mathrm{yr}^{-1}$ ), as shown in Table 1.

The results showed that the temperature was significantly correlated with $\mathrm{CH}_{4}$ emission, with Cilacap having $\mathrm{R}^{2}=0.34$. In contrast, statistical analysis showed that temperature did not significantly affect $\mathrm{N}_{2} \mathrm{O}$ in the rice field in this study site. Table 2 shows that the temperature was significantly correlated with $\mathrm{CH}_{4}$ emission (Cilacap (0.58), Karanganyar $(-0.18)$, and Pati (0.05)). In contrast, statistical analysis showed that the temperature did not significantly affect the $\mathrm{N}_{2} \mathrm{O}$ emission, for Karanganyar only.

\subsection{Correlation between climate, soil moisture, rice production, and $\mathrm{N}_{2} \mathrm{O}$ and $\mathrm{CH}_{4}$ emissions}

Climate change is a vital environmental issue that significantly affects rice productivity. Rice paddy fields are one of the greatest anthropogenic sources of $\mathrm{N}_{2} \mathrm{O}$ and $\mathrm{CH}_{4}$ emissions. The results showed that the annual rice production significantly $\left(\mathrm{R}^{2}=0.81\right)$ affected the $\mathrm{CH}_{4}$ emissions in Cilacap, only. Meanwhile, the annual rice production significantly affected the $\mathrm{N}_{2} \mathrm{O}$ emission in Cilacap and Karanganyar (0.36), while Pati (0.34) as shown in Table 2. In addition, soil moisture has affected $\mathrm{CH}_{4}$ and $\mathrm{N}_{2} \mathrm{O}$ emissions over study sites, as shown in Figure 5.

Table 1. Flux rates of $\mathrm{CH}_{4}$ and $\mathrm{N}_{2} \mathrm{O}$ from 2005 to 2010 in the study sites.

\begin{tabular}{|c|c|c|c|c|c|c|}
\hline \multirow{2}{*}{ Year } & \multicolumn{3}{|c|}{$\mathrm{CH}_{4}\left[\mathrm{~kg} \mathrm{Cha} \mathrm{Cr}^{-1} \mathrm{yr}^{-1}\right]$} & \multicolumn{3}{|c|}{$\mathrm{N}_{2} \mathrm{O}\left[\mathrm{kg} \mathrm{N} \mathrm{ha}^{-1} \mathrm{yr}^{-1}\right]$} \\
\hline & Cilacap & Karanganyar & Pati & Cilacap & Karanganyar & Pati \\
\hline 2005 & 280.15 & 186.06 & 374.04 & 20.11 & 18.68 & 13.66 \\
\hline 2006 & 269.95 & 173.37 & 359.28 & 17.65 & 16.13 & 11.51 \\
\hline 2007 & 272.20 & 227.84 & 363.60 & 17.89 & 19.65 & 11.85 \\
\hline 2008 & 267.84 & 224.88 & 360.06 & 20.08 & 22.04 & 15.02 \\
\hline 2009 & 259.40 & 232.42 & 342.67 & 15.60 & 14.89 & 9.62 \\
\hline 2010 & 274.32 & 237.59 & 363.86 & 21.42 & 22.62 & 15.27 \\
\hline Average & 270.65 & 213.69 & 360.58 & 18.79 & 19.00 & 12.82 \\
\hline
\end{tabular}



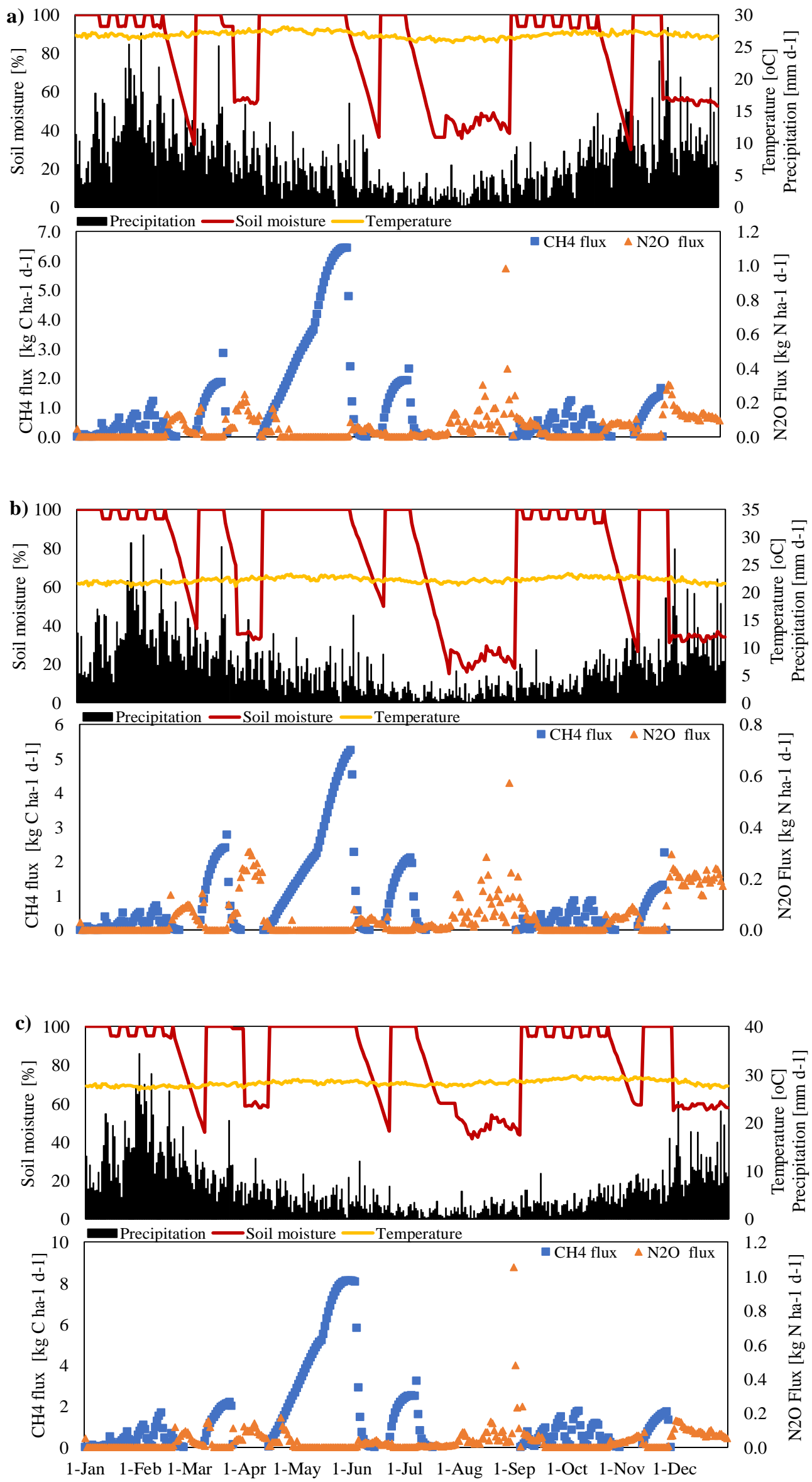

Figure 4. Seasonal variability of daily average precipitation, temperature, and soil moisture as well as of soil nitrous oxide and methane fluxes at (a) Cilacap, (b) Karanganyar, and (c) Pati sites in 2005-2010. 
Table 2. Pearson's correlation $(r)$ between climate, soil moisture, and rice production on $\mathrm{CH}_{4}$ and $\mathrm{N}_{2} \mathrm{O}$ emissions.

\begin{tabular}{ccccccc}
\hline \multirow{2}{*}{ Variables } & \multicolumn{3}{c}{$\mathrm{CH}_{4}$} & \multicolumn{3}{c}{$\mathrm{N}_{2} \mathrm{O}$} \\
\cline { 2 - 7 } & Cilacap & Karanganyar & Pati & Cilacap & Karanganyar & Pati \\
\hline Precipitation & $0.280^{*}$ & $0.692^{*}$ & $0.081^{*}$ & $0.593^{*}$ & $0.661^{*}$ & $0.228^{*}$ \\
Temperature & $0.580^{*}$ & $-0.182^{*}$ & $0.052^{*}$ & $-0.097^{*}$ & $0.175 \mathrm{~ns}$ & $-0.521^{*}$ \\
Soil moisture & $0.748^{*}$ & $0.323^{*}$ & $0.810^{*}$ & $0.973^{*}$ & $0.981^{*}$ & $0.810^{*}$ \\
Rice production & $-0.102^{*}$ & $0.810^{*}$ & $-0.289^{*}$ & $0.364^{*}$ & $0.365^{*}$ & $0.344^{*}$ \\
\hline
\end{tabular}

Notes: $\alpha=0.05 ;{ }^{*}$ : significant; ns: no significant.

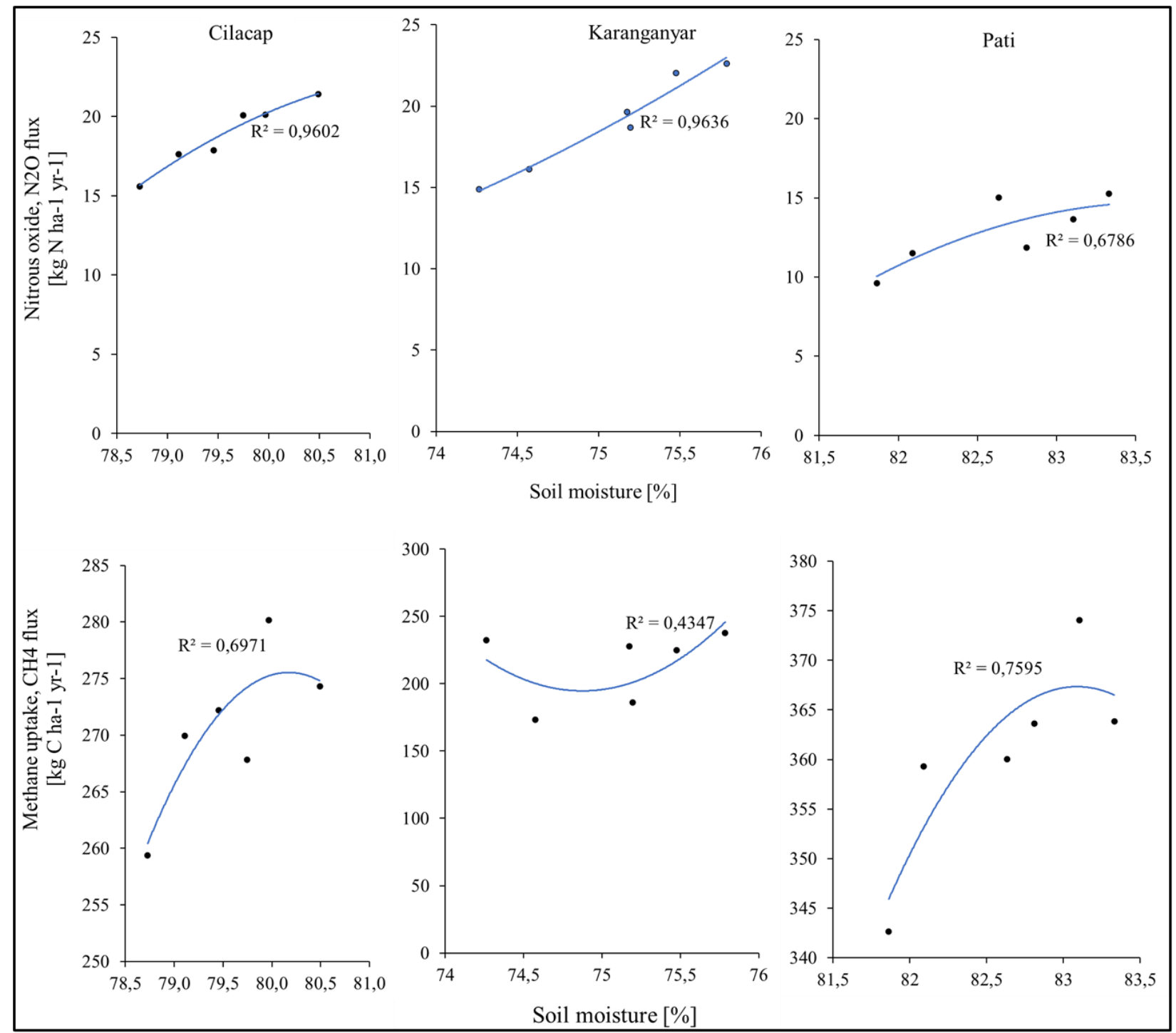

Figure 5. Regression of soil moisture and greenhouse gas fluxes in the study sites in the period of 2005-2010.

Figure 5 shows that increasing soil moisture consistently enhanced the $\mathrm{N}_{2} \mathrm{O}$ flux at all areas, with a linear regression pattern. However, the pattern of $\mathrm{CH}_{4}$ flux increases was parabolic, which means that the increasing soil moisture would enhance the $\mathrm{CH}_{4}$ emission but at a certain point (peak) it would decrease. However, the pattern of $\mathrm{CH}_{4}$ emission related to soil moisture was inconsistent in the Karanganyar District, which shows a decline along with a soil moisture increase but enhanced after a particular point.

\section{DISCUSSION}

In the Karanganyar, Cilacap, and Pati Districts, the $\mathrm{N}_{2} \mathrm{O}$ emissions from rice farming were $19.0,18.8$, and $12.8 \mathrm{~kg} \mathrm{~N}$ $\mathrm{ha}^{-1} \mathrm{yr}^{-1}$ and the $\mathrm{CH}_{4}$ emissions were $213.7,270.6$, and 360.6 kg C ha- $\mathrm{yr}^{-1}$, respectively. The $\mathrm{N}_{2} \mathrm{O}$ and $\mathrm{CH}_{4}$ emissions in the surroundings were due to precipitation, temperature, soil moisture, and rice productivity (Table 2 ). The climate variables influence the biogeochemical processes, which in turn influence the soil GHG fluxes (Timilsina et al., 2020).

Overall, the temperature significantly correlated with nitrous oxide emission and the changing of methane emission over study area (Figure 3). However, the temperature at Karanganyar Regency was not correlated with $\mathrm{N}_{2} \mathrm{O}$ emissions, probably due to lower air temperature and precipitation in Karanganyar Regency than in Cilacap and Pati Regencies. In other words, lower temperature and precipitation promote a smaller influence on nitrous oxide emissions because warmer and wetter weather enhances nitrous oxide emissions (Griffis 
et al., 2017). Further, the increasing temperature affects the availability of soil moisture, which can change the flux of $\mathrm{N}$ from the soil as $\mathrm{N}_{2} \mathrm{O}$ emissions (Liu et al., 2017; Liu et al., 2015). In addition, the three major processes that cause methane emissions from rice fields, namely, production, oxidation, and transport (Wang et al., 2018). The rate at which bacteria can degrade organic matter is a chain of steps, and each step is temperature-dependent, thereby causing variability in the system; Similarly, methanotrophic bacteria that oxidize methane are also stimulated by an increase in temperature (Lu et al., 2015). Therefore, temperature, along with soil moisture, is one of the most influential environmental factors affecting the rate of nutrient cycling and the production of greenhouse gases in the soil such as $\mathrm{CH}_{4}$ and $\mathrm{N}_{2} \mathrm{O}$, contributing to global warming and in turn being almost influenced by climate change (Liu et al., 2017).

$\mathrm{CH}_{4}$ and $\mathrm{N}_{2} \mathrm{O}$ emissions tended to increase during rather longer rainy days (Figure 4), which significantly correlated with soil moisture, values of which were 0.559 and 0.946 ; 0.104 and $0.961 ; 0.656$ and 0.655 , for Cilacap, Karanganyar, and Pati. This is in line with a previous report (D'Imperio et al., 2017) that soil moisture was the crucial factor influencing $\mathrm{CH}_{4}$ and $\mathrm{N}_{2} \mathrm{O}$ emissions from soils. When there is precipitation for some consecutive days, soil moisture will increase, thus instantaneously influencing the soil microbes, soil $\mathrm{pH}$, bulk density, and soil pore space, hence releasing the GHG fluxes (Li et al., 2020). In addition, the $\mathrm{N}_{2} \mathrm{O}$ emissions increase under successive moist and dry periods (Zhang \& Niu, 2016). Moreover, the soil drying and wetting cycles caused by precipitation stimulated the mineralization of soil organic matter, resulting in rapid soil carbon losses; such a phenomenon is called the "Birch effect" (Birch, 1964).

This study found the significant correlation of rice production with the $\mathrm{N}_{2} \mathrm{O}$ emissions in Central Java, Indonesia. The main reason for $\mathrm{N}_{2} \mathrm{O}$ emissions from agricultural soils is the application of inorganic fertilizers and/or manure when plants cannot absorb all of the nitrogen $(\mathrm{N})$ provided because the growth stage does not require all of them (Wang et al., 2021), making the zones of $\mathrm{N}_{2} \mathrm{O}$ formation more potential. Similar findings were also reported where the application of $\mathrm{N}$ fertilization (Zhao et al., 2019) and irrigation management practices (Jiang et al., 2019) contributed to $\mathrm{N}_{2} \mathrm{O}$ emissions. Because the global demand for rice production increases with population growth (FAO, 2017) and higher atmospheric $\mathrm{N}_{2} \mathrm{O}$ concentrations (global average $1875 \mathrm{ppb}$ ) raise concerns about global warming (Tian et al., 2016), an effective management strategy is needed to reduce GHG emissions while maintaining high rice yields (Islam et al., 2018).

Because Indonesia is the third largest rice producer and as the fourth most populous country in the world, and also one of the world's main rice consumers (GRiSP, 2013), rice is grown in the major islands of Indonesia, but most rice is cultivated in Java on an estimated land area of 3.1 million ha (Ministry of Agriculture, 2018). However, because agricultural land is a major contributor to $\mathrm{CH}_{4}$ and $\mathrm{N}_{2} \mathrm{O}$ emissions (Zhou et al., 2014), it is very important to have a comprehensive understanding of the feedback between agricultural soils (that is, rice) and the ongoing climate change crisis (that is, GHG emissions) in Indonesia. Monitoring the $\mathrm{CH}_{4}$ and $\mathrm{N}_{2} \mathrm{O}$ emissions will contribute to support decision-making toward sustainable agriculture for the Indonesian government and relevant stakeholders. This study proves that the DNDC model can possibly predict the $\mathrm{CH}_{4}$ and $\mathrm{N}_{2} \mathrm{O}$ emissions in Central Java when incorporated with various secondary climatic and land management big data resources.

\section{CONCLUSIONS}

The DNDC model estimated that the $\mathrm{N}_{2} \mathrm{O}$ and $\mathrm{CH}_{4}$ emissions in Central Java, Indonesia, from 2005 to 2010 reached 18.8 and 270.6; 19.0 and 213.7; and 12.8 and 360.6 $\mathrm{kg} \mathrm{N} / \mathrm{C} \mathrm{ha}^{-1} \mathrm{yr}^{-1}$ in the Cilacap, Karanganyar, and Pati regions, respectively. The major factors influencing the emissions were precipitation, temperature, soil moisture, and rice productivity in each region. Since fertilizer input and irrigation practices may contribute to the $\mathrm{N}_{2} \mathrm{O}$ and $\mathrm{CH}_{4}$ emissions, further studies on agricultural practices on the emissions are suggested.

\section{Acknowledgments}

The authors acknowledge Sebelas Maret University for providing BEASISWA UNS scholarship and the Japan Student Services Organization, Japan (JASSO) through a sandwich program in Gifu University to support this research.

\section{Declaration of Competing Interest}

The authors declare no competing financial or personal interests that may appear and influence the work reported in this paper.

\section{References}

Abdalla, M., Song, X., Ju, X., Topp, C. F. E., \& Smith, P. (2020). Calibration and validation of the DNDC model to estimate nitrous oxide emissions and crop productivity for a summer maize-winter wheat double cropping system in Hebei, China. Environmental Pollution, 262, 114199.

https://doi.org/10.1016/j.envpol.2020.114199

Ariani, M., Haryono, E., \& Hanudin, E. (2021). Greenhouse Gas Emission from Rice field in Indonesia: Challenge for future research and development [GHG emission; rice field; Indonesia; future research]. 2021, 53(1), 14. https://doi.org/10.22146/ijg.55681

Beaulieu, J. J., Tank, J. L., Hamilton, S. K., Wollheim, W. M., Hall, R. O., Mulholland, P. J., Peterson, B. J., Ashkenas, L. R., Cooper, L. W., Dahm, C. N., Dodds, W. K., Grimm, N. B., Johnson, S. L., McDowell, W. H., Poole, G. C., Valett, H. M., Arango, C. P., Bernot, M. J., Burgin, A. J., Crenshaw, C. L., Helton, A. M., Johnson, L. T., Brien, J. M., Potter, J. D., Sheibley, R. W., Sobota, D. J., \& Thomas, S. M. (2011). Nitrous oxide emission from denitrification in stream and river networks. Proceedings of the National Academy of Sciences, 108(1), 214. https://doi.org/10.1073/pnas.1011464108

Birch, H. F. (1964). Mineralisation of plant nitrogen following alternate wet and dry conditions. Plant and Soil, 20(1), 43-49. https://doi.org/10.1007/BF01378096 
Birla, D. S., Malik, K., Sainger, M., Chaudhary, D., Jaiwal, R., \& Jaiwal, P. K. (2017). Progress and challenges in improving the nutritional quality of rice (Oryza sativa L.). Critical Reviews in Food Science and Nutrition, 57(11), 2455-2481. https://doi.org/10.1080/10408398.2015.1084992

BMKG. (2019). Peraturan Badan Meteorologi, Klimatologi, dan Geofika Republik Indonesia Nomor 9 Tahun 2019 tentang Penyediaan dan Penyebaran Peringatan Dini Iklim Ekstrim. Badan Meteorologi, Klimatologi, dan Geofika Republik Indonesia http://jdih.bmkg.go.id/vifiles/PENYEDIAAN\%20DAN\% 20PENYEBARAN\%20PERINGATAN\%20DINI\%20IKLIM\% 20EKSTRIM\%20NO-9\%202019.PDF

BPS. (2021). Harvested Area, Productivity, and Production of Paddy by Province 2019-2021. BPS - Statistics Indonesia,.

https://www.bps.go.id/indicator/53/1498/1/luaspanen-produksi-dan-produktivitas-padi-menurutprovinsi.html

Ciais, P., Sabine, C., Bala, G., Bopp, L., Brovkin, V., Canadell, J., Chhabra, A., DeFries, R., Galloway, J., Heimann, M., Jones, C., Quéré, C. L., Myneni, R. B., Piao, S., \& Thornton, P. (2013). Carbon and other biogeochemical cycles. In T. F. Stocker, D. Qin, G.-K. Plattner, M. Tignor, S. K. Allen, J. Boschung, A. Nauels, Y. Xia, V. Bex, \& P. M. Midgley (Eds.), Climate change 2013: the physical science basis. Contribution of Working Group I to the Fifth Assessment Report of the Intergovernmental Panel on Climate Change (pp. 465-570). Cambridge University Press, Cambridge, United Kingdom and New York, NY, USA https://www.ipcc.ch/site/assets/uploads/2018/02/W G1AR5_Chapter06_FINAL.pdf

Connor, M., de Guia, A. H., Pustika, A. B., Sudarmaji, Kobarsih, M., \& Hellin, J. (2021). Rice Farming in Central Java, Indonesia-Adoption of Sustainable Farming Practices, Impacts and Implications. Agronomy, 11(5), 881. https://doi.org/10.3390/agronomy11050881

D'Imperio, L., Nielsen, C. S., Westergaard-Nielsen, A., Michelsen, A., \& Elberling, B. (2017). Methane oxidation in contrasting soil types: responses to experimental warming with implication for landscapeintegrated $\mathrm{CH} 4$ budget. Global Change Biology, 23(2), 966-976. https://doi.org/10.1111/gcb.13400

FAO. (2017). The future of food and agriculture: Trends and challenges. Food and Agriculture Organization of the United Nations. Rome. https://www.fao.org/3/i6583e/i6583e.pdf?_cf_chl_ managed_tk_=oWmmr9KgEIAzfdtwstkKyNly2R56B9 RI.mA.Y7cxkJY-1641792729-0-gaNycGzNCJE

Gilhespy, S. L., Anthony, S., Cardenas, L., Chadwick, D., del Prado, A., Li, C., Misselbrook, T., Rees, R. M., Salas, W., Sanz-Cobena, A., Smith, P., Tilston, E. L., Topp, C. F. E., Vetter, S., \& Yeluripati, J. B. (2014). First 20 years of DNDC (DeNitrification DeComposition): Model evolution. Ecological Modelling, 292, 51-62. https://doi.org/10.1016/j.ecolmodel.2014.09.004
Griffis, T. J., Chen, Z., Baker, J. M., Wood, J. D., Millet, D. B., Lee, X., Venterea, R. T., \& Turner, P. A. (2017). Nitrous oxide emissions are enhanced in a warmer and wetter world. Proceedings of the National Academy of Sciences, 114(45), 12081. https://doi.org/10.1073/pnas.1704552114

GRiSP. (2013). Rice Almanac (4th ed.). GRiSP (Global Rice Science Partnership), International Rice Research Institute. Los Banos, Philippines.

Han, J., Jia, Z., Wu, W., Li, C., Han, Q., \& Zhang, J. (2014). Modeling impacts of film mulching on rainfed crop yield in Northern China with DNDC. Field Crops Research, 155, 202-212. https://doi.org/10.1016/j.fcr.2013.09.004

Husnain, Widowati, L. R., Las, I., Sarwani, M., Rochayati, S., Setyorini, D., Hartatik, W., Subiksa, I. G. M., Suastika, I. W., Angria, L., Kasno, I., INurjaya, Wibowo, H., Zakiah, K., Aksani, D., Hatta, M., Ratmini, N. P. S., Barus, Y., Annisa, W., \& Susilawati. (2020). Rekomendasi pupuk $N, P, K$ spesifik lokasi untuk tanaman padi, jagung, dan kedelai pada lahan sawah per kecamatan. Buku I: PADI (F. F. Agung, A. P. Saputra, \& T. P. Wijaya, Eds.). Badan Penelitian Dan Pengembangan Pertanian Kementerian Pertanian.

https://bbsdlp.litbang.pertanian.go.id/ind/images/PA JALAI/Buku-I-Padi_Final.pdf

Islam, S. F.-U., van Groenigen, J. W., Jensen, L. S., Sander, B. O., \& de Neergaard, A. (2018). The effective mitigation of greenhouse gas emissions from rice paddies without compromising yield by early-season drainage. Science of The Total Environment, 612, 1329-1339. https://doi.org/10.1016/j.scitotenv.2017.09.022

Jiang, Y., Carrijo, D., Huang, S., Chen, J., Balaine, N., Zhang, W., van Groenigen, K. J., \& Linquist, B. (2019). Water management to mitigate the global warming potential of rice systems: A global meta-analysis. Field Crops Research, 234, 47-54. https://doi.org/10.1016/j.fcr.2019.02.010

Kim, G. W., Kim, P. J., Khan, M. I., \& Lee, S.-J. (2021). Effect of Rice Planting on Nitrous Oxide (N2O) Emission under Different Levels of Nitrogen Fertilization. Agronomy, 11(2), 217. https://doi.org/10.3390/agronomy11020217

Li, C., Frolking, S., \& Frolking, T. A. (1992a). A model of nitrous oxide evolution from soil driven by rainfall events: 1 . Model structure and sensitivity. Journal of Geophysical Research: Atmospheres, 97(D9), 9759-9776. https://doi.org/10.1029/92JD00509

Li, C., Frolking, S., \& Frolking, T. A. (1992b). A model of nitrous oxide evolution from soil driven by rainfall events: 2 . Model applications. Journal of Geophysical Research: Atmospheres, 97(D9), 9777-9783. https://doi.org/10.1029/92JD00510

Li, H., Wang, L., Li, J., Gao, M., Zhang, J., Zhang, J., Qiu, J., Deng, J., Li, C., \& Frolking, S. (2017). The development of China-DNDC and review of its applications for sustaining Chinese agriculture. Ecological Modelling, 348, 1-13. https://doi.org/10.1016/j.ecolmodel.2017.01.003 
Li, X., Gao, J., Guo, Z., Yin, Y., Zhang, X., Sun, P., \& Gao, Z. (2020). A Study of Rainfall-Runoff Movement Process on High and Steep Slopes Affected by Double Turbulence Sources. Scientific Reports, 10(1), 9001. https://doi.org/10.1038/s41598-020-66060-3

Liu, R., Hayden, H. L., Suter, H., Hu, H., Lam, S. K., He, J., Mele, P. M., \& Chen, D. (2017). The effect of temperature and moisture on the source of $\mathrm{N} 2 \mathrm{O}$ and contributions from ammonia oxidizers in an agricultural soil. Biology and Fertility of Soils, 53(1), 141-152. https://doi.org/10.1007/s00374-016-1167-8

Liu, Y., Ni, B.-J., Sharma, K. R., \& Yuan, Z. (2015). Methane emission from sewers. Science of The Total Environment, 524-525, 40-51. https://doi.org/10.1016/j.scitotenv.2015.04.029

Lu, Y., Fu, L., Lu, Y., Hugenholtz, F., \& Ma, K. (2015). Effect of temperature on the structure and activity of a methanogenic archaeal community during rice straw decomposition. Soil Biology and Biochemistry, 81, 1727. https://doi.org/10.1016/j.soilbio.2014.10.031

Minamikawa, K., Fumoto, T., Itoh, M., Hayano, M., Sudo, S., \& Yagi, K. (2014). Potential of prolonged midseason drainage for reducing methane emission from rice paddies in Japan: a long-term simulation using the DNDC-Rice model. Biology and Fertility of Soils, 50(6), 879-889. https://doi.org/10.1007/s00374-014-0909-8

Ministry of Agriculture. (2018). Agricultural Statistics 2018 (A. A. Susanti \& B. Waryanto, Eds.). Center for Agricultural Data and Information System, Ministry of Agriculture Republic of Indonesia. http://epublikasi.setjen.pertanian.go.id/download/fil e/438-statistik-pertanian-2018

Muthayya, S., Sugimoto, J. D., Montgomery, S., \& Maberly, G. F. (2014). An overview of global rice production, supply, trade, and consumption. Annals of the New York Academy of Sciences, 1324(1), 7-14. https://doi.org/10.1111/nyas. 12540

Nungkat, P., Kusuma, Z., \& Handayanto, E. (2015). Effects of organic matter application on methane emission from paddy fields adopting organic farming system [methane; organic fertilizers; rice cultivars]. 2015, 2(2), 10. https://doi.org/10.15243/jdmlm.2014.022.303

Oo, A. Z., Sudo, S., Inubushi, K., Mano, M., Yamamoto, A., Ono, K., Osawa, T., Hayashida, S., Patra, P. K., Terao, Y., Elayakumar, P., Vanitha, K., Umamageswari, C., Jothimani, P., \& Ravi, V. (2018). Methane and nitrous oxide emissions from conventional and modified rice cultivation systems in South India. Agriculture, Ecosystems \& Environment, 252, 148-158. https://doi.org/10.1016/j.agee.2017.10.014

Seitzinger, S. P., \& Phillips, L. (2017). Nitrogen stewardship in the Anthropocene. Science, 357(6349), 350-351. https://doi.org/10.1126/science.aao0812

Setyanto, P., Pramono, A., Adriany, T. A., Susilawati, H. L., Tokida, T., Padre, A. T., \& Minamikawa, K. (2018). Alternate wetting and drying reduces methane emission from a rice paddy in Central Java, Indonesia without yield loss. Soil Science and Plant Nutrition,
64(1),

https://doi.org/10.1080/00380768.2017.1409600

Smith, K. A. (2017). Changing views of nitrous oxide emissions from agricultural soil: key controlling processes and assessment at different spatial scales. European Journal of Soil Science, 68(2), 137-155. https://doi.org/10.1111/ejss.12409

Susilawati, H. L., Setyanto, P., Makarim, A. K., Ariani, M., Ito, K., \& Inubushi, K. (2015). Effects of steel slag applications on $\mathrm{CH} 4, \mathrm{~N} 2 \mathrm{O}$ and the yields of Indonesian rice fields: a case study during two consecutive ricegrowing seasons at two sites. Soil Science and Plant Nutrition, 61(4), 704-718. https://doi.org/10.1080/00380768.2015.1041861

Tian, H., Lu, C., Ciais, P., Michalak, A. M., Canadell, J. G., Saikawa, E., Huntzinger, D. N., Gurney, K. R., Sitch, S., Zhang, B., Yang, J., Bousquet, P., Bruhwiler, L., Chen, G., Dlugokencky, E., Friedlingstein, P., Melillo, J., Pan, S., Poulter, B., Prinn, R., Saunois, M., Schwalm, C. R., \& Wofsy, S. C. (2016). The terrestrial biosphere as a net source of greenhouse gases to the atmosphere. Nature, 531(7593), 225-228. https://doi.org/10.1038/nature16946

Timilsina, A., Bizimana, F., Pandey, B., Yadav, R. K. P., Dong, W., \& Hu, C. (2020). Nitrous Oxide Emissions from Paddies: Understanding the Role of Rice Plants. Plants, 9(2), 180. https://doi.org/10.3390/plants9020180

Tubiello, F. N., Salvatore, M., Golec, R. D. C., A. Ferrara, S. R., Biancalani, R., Federici, S., Jacobs, H., \& Flammini, A. (2014). Agriculture, Forestry and Other Land Use Emissions by Sources and Removals by Sinks. ESS Working Paper, 2, 1-75. https://www.fao.org/3/i3671e/i3671e.pdf

Wang, C., Jin, Y., Ji, C., Zhang, N., Song, M., Kong, D., Liu, S., Zhang, X., Liu, X., Zou, J., Li, S., \& Pan, G. (2018). An additive effect of elevated atmospheric $\mathrm{CO} 2$ and rising temperature on methane emissions related to methanogenic community in rice paddies. Agriculture, Ecosystems \& Environment, 257, 165-174. https://doi.org/10.1016/j.agee.2018.02.003

Xu, Y., Ge, J., Tian, S., Li, S., Nguy-Robertson, A. L., Zhan, M., \& Cao, C. (2015). Effects of water-saving irrigation practices and drought resistant rice variety on greenhouse gas emissions from a no-till paddy in the central lowlands of China. Science of The Total Environment, 505, 1043-1052. https://doi.org/10.1016/j.scitotenv.2014.10.073

Zhang, X., Bi, J., Sun, H., Zhang, J., \& Zhou, S. (2019). Greenhouse gas mitigation potential under different rice-crop rotation systems: from site experiment to model evaluation. Clean Technologies and Environmental Policy, 21(8), 1587-1601. https://doi.org/10.1007/s10098-019-01729-6

Zhang, Y., \& Niu, H. (2016). The development of the DNDC plant growth sub-model and the application of DNDC in agriculture: A review. Agriculture, Ecosystems \& Environment, 230, 271-282. https://doi.org/10.1016/j.agee.2016.06.017 
Zhang, Y., Shou, W., Maucieri, C., \& Lin, F. (2021). Rainfall increasing offsets the negative effects of nighttime warming on GHGs and wheat yield in North China Plain. Scientific Reports, 11(1), 6505. https://doi.org/10.1038/s41598-021-86034-3

Zhao, X., Pu, C., Ma, S.-T., Liu, S.-L., Xue, J.-F., Wang, X., Wang, Y.-Q., Li, S.-S., Lal, R., Chen, F., \& Zhang, H.-L. (2019). Management-induced greenhouse gases emission mitigation in global rice production. Science of The Total Environment, 649, 1299-1306. https://doi.org/10.1016/j.scitotenv.2018.08.392
Zhao, Z., Cao, L., Deng, J., Sha, Z., Chu, C., Zhou, D., Wu, S., \& Lv, W. (2020). Modeling $\mathrm{CH} 4$ and N2O emission patterns and mitigation potential from paddy fields in Shanghai, China with the DNDC model. Agricultural Systems, 178, 102743. https://doi.org/10.1016/j.agsy.2019.102743

Zhou, F., Shang, Z., Ciais, P., Tao, S., Piao, S., Raymond, P., He, C., Li, B., Wang, R., Wang, X., Peng, S., Zeng, Z., Chen, H., Ying, N., Hou, X., \& Xu, P. (2014). A New HighResolution N2O Emission Inventory for China in 2008. Environmental Science \& Technology, 48(15), 85388547. https://doi.org/10.1021/es5018027 